\title{
Using Children's Literature to Teach Mathematics: An Effective Vehicle in a STEM World
}

\author{
Joseph M. Furner ${ }^{1 *}$ \\ ${ }^{1}$ Ph.D., Florida Atlantic University, 5353 Parkside Drive, EC 207D, 33458 Jupiter, USA
}

*Corresponding Author: jfurner@fau.edu

Citation: Furner, J. M. (2018). Using Children's Literature to Teach Mathematics: An Effective Vehicle in a STEM World. European Journal of STEM Education, 3(3), 14. https://doi.org/10.20897/ ejsteme/3874

Published: September 6, 2018

\begin{abstract}
Today it is critical to excite young people about mathematics in our high-tech STEM world we live in. Math teachers today need to embolden students to be confident in their ability to solve problems, to think and use their imaginations, to understand mathematical concepts, to be creative, and to see math as a human endeavor. The author feels that as students feel less anxious about, and more confident in their abilities to do math their performance will improve. The author has provided an in-depth literature review and offers background information on using children's literature to teach mathematics; sharing the methods and materials possible to incorporate such literature into such math instruction in a wide range of mathematics strands. The results of using such literature in the teaching of mathematics may help to lower math anxiety and pique students interest and confidence in math and the STEM fields. Teachers need to address this alarming problem and work toward developing mathematically confident young people for a world where Science, Technology, Engineering, and Mathematics (STEM) fields dominate the globe, using literature to teach mathematics can support and cultivate students' math confidence for a STEM world.
\end{abstract}

Keywords: children's literature, STEM, creativity, bibliotherapy, reading

\section{INTRODUCTION}

"I think that children's literature offers a wonderful vebicle for helping teachers teach math well."

-Marilyn Burns

"If you want your children to be intelligent, read them fairy tales. If you want them to be more intelligent, read them more fairy tales." -Albert Einstein 1879-1955

Today math teachers may want to read the children's book and fairy tale Sir Cumference and the Dragon of Pi, a Math Adventure (Neuschwander, 2004) See Figure 1, the son Radius (the name is referred to but not described in math terms) saves his father's life, Sir Cumference, after accidentally turning him into a fire-breathing dragon. Of course, a math formula is the reason for the solution. Did you know Sir Cumference named Pi in this story? Did you know this story tells how the math formula for $\prod$ was discovered? This is a fictional story but the author's purpose is achieved when children remember this math lesson and what Pi really means.

\section{BUILDING MATH CONFIDENCE FOR A STEM WORLD}

We currently live in an age of advancing technologies that are constantly advancing. Young people need to be literate as well as be very good at mathematics and problem solving in order to compete in a global society. A 


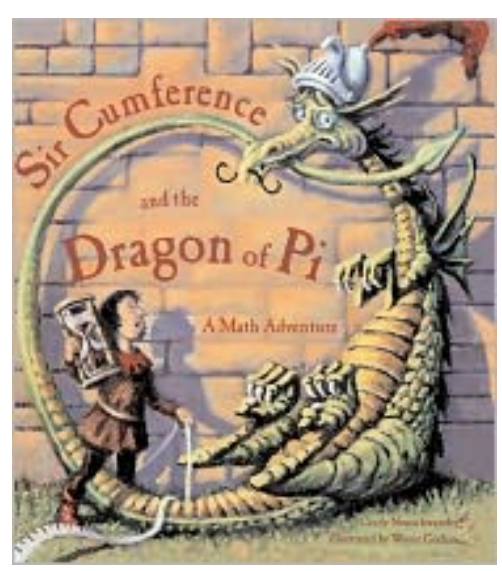

Figure 1. Book Cover Image

young person's lack of confidence and ability to do mathematics may influence his/her entire life forever both in all decisions they make on a daily basis as well as future career choices. Today math teachers need to be equipped to touch all youngsters so to improve their confidence and capacity to do mathematics. Teachers should check to see that all children have positive attitudes and dispositions toward math (NCTM, 1989). In her book, Boaler (2008) feels it is critical to ensure our young people are confident and well prepared in mathematics if they are going to compete for such high-tech jobs today and in the future. Today, the United States is working to lead more young people into the fields of Science, Technology, Engineering, and Mathematics (STEM) so we as a country can better vie globally. If we are to build math confidence in our students, math teachers need to address head on the issue of math anxiety, which often manifests itself as uncertainty or learned helplessness in perceived math achievement (Furner, 2016). Burns (1998) and Jackson and Leffingwell (1999) both found that Americans do not care for mathematics. Burns cited that two-thirds of Americans loathe math and research done by Jackson and Leffingwell revealed that only about $7 \%$ of Americans reported having positive experiences while taking math classes at the Kindergarten through college levels. This is alarming in our information age where mathematics plays such a critical role in the world. Sparks (2011) feels that as the STEM areas become more important for our students to study, our schools and teachers need to do more to address math anxiety so that our students are selfconfident to study areas related to STEM fields. With the NCTM Standards pushing for more communications in mathematics instruction (NCTM, 1989 and 2000) and the push to incorporate literature in the teaching of mathematics, teachers are now able to make better connections to mathematics and students' lives (Furner, 2017b). Today there are literally thousands of children's literature books out there to teach mathematics, this paper will share several of them, advocating their use (See Appendix and A and B for an extensive list of math related literature).

\section{USING CHILDREN'S LITERATURE TO TEACH MATHEMATICS}

For about the past two or three decades now children's and adolescent literature has been recognized as a means to teaching mathematics concepts to students through the use of stories to make mathematics ideas relevant and meaningful during instruction. Children's literature may also be used as a form of therapy (bibliotherapy) to reach learners who may be frustrated with being taunted or teased for excelling in mathematics of for having math anxiety. Rozalski et al. (2010) have found that using sensibly selected thematic stories; teachers can use literature to reach young people who are experiencing difficult situations in learning and in life. Barnaby (2015) found in a qualitative case study research project that the use of children's literature in the teaching of mathematics was an effective means for teaching mathematics and helped in addressing math anxiety in students while teaching math. Muir et al. (2017) describe the groundwork for using math literature during math instructions and offers math activities and children's books in their book to use for teaching many elementary math concepts using picture books in today's classrooms. McAndrew et al. (2017) found in their quasi-experimental study that by using children's literature, specifically, Geometry-related children's literature improves the geometry success and

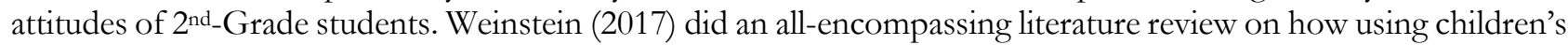
literature is effective in covering the new Common Core State Math Standards and gives an all-inclusive list of children's literature to use to model and teach many math concepts covered today in elementary school.

In today's classrooms, teachers can use children's literature to reach a child in a non-threatening way by reading literature that can help to teach math concepts and really connect to the mathematical understanding of the learner and at the same time not intimidate, threaten or turn-off a child to mathematics like some traditional approaches 
may have in the past. Children's and adolescent literature can be a beneficial way of teaching mathematics (See Appendix A and B).

Some Benefits of Using Literature in Mathematics Instruction Include:

- Math ideas are taught in the context of a story

- Combines integrated studies with reading, writing, speaking, listening, etc.

- Advances mathematical thinking

- Thwarts math anxiety and creates a less math anxious classroom milieu

- Permits for a variety of responses

- Allows for historical, cultural, and practical applications and connections

- May promote the use of certain math manipulatives as it relates to the story

- A teacher can evaluate a child's understanding by reading/questioning

- Currently there is a wide range of books to use in teaching most math concepts K-8

- Lends itself to problem solving and active involvement from the context of the story

- Affords for a shared experience for both students and the teacher (Furner, 2017a and b; Furner and Kenney, 2011; Furner and Duffy, 2002)

Math teachers can address the NCTM's "Communication Standard" by incorporating literature in the teaching of mathematics as well as by having students discuss math from the stories and write about such concepts in mathematics to demonstrate their understanding of math concepts as well as their feelings toward math (NCTM, 1989). Griffiths and Clyne (1991) in their book, Books you can Count on: Linking Mathematics and Literature, wonderfully illustrates countless examples of how to connect children's literature into a math lesson. Included below is a sample of some suggested activities tying literature into the teaching of mathematics. It is important to mention a distinction between using literature in the teaching of mathematics. Math teachers may use literature to introduce, teach, reinforce, and to make connections to many math concepts through the use of story books that have mathematics uses. There are also books that may be used to assist students with helping them come to terms with things like fear of mathematics for example, the book, Math Curse (Scieszka and Smith, 1995) or the book, Counting on Frank (Clement, 1991), which can be used to help gifted math students to accept and respect their giftedness with mathematics (Furner and Kenney, 2011).

\section{USING BIBLIOTHERAPY WHILE TEACHING MATHEMATICS}

Today affective factors play such an important role in learning mathematics (McLeod, 1992) and teachers need classroom approaches that are practical so to address the feelings of their students suffering from mathematics anxiety. Teachers need to create supportive environments in which their students feel at ease expressing how they are feeling about their current and past mathematical experiences. A psychological method to assist people to feel more at ease with an issue or situation is by using bibliotherapy. Bibliotherapy is the reading of pre-selected books in order to create change in attitude so to improve character development and growth progress toward an issue or concern of the individual (Abdullah, 2002; Betzalel and Shechtman, 2010; Doll and Doll, 1997; Forgan, 2002, 2003; Furner, 2004; Jeon, 1992; Heath et al., 2005; Jack and Ronan, 2008; Lenkowsky, 1987; Reis and Renzulli, 2004; Rozalski et al., 2010; Sridhar and Vaughn, 2000; Sullivan and Strang, 2003). Bibliotherapy may be used as an endeavor to help students better understand themselves and deal with problems by sharing pertinent literature to their personal circumstances and evolving needs (Betzalel and Shechtman, 2010). Hébert and Kent (2000) strongly believe teachers need to use literature geared toward young gifted teens so to address societal and emotional apprehensions. Teachers using this approach hold a fundamental belief that reading will impact thinking and comportment, and that through guided discussions designated readings may be concentrated on the exact needs of students as well. Reading children's literature, fairy tales, and stories while teaching math concepts can allow students to invoke more creativity and employ their imaginations further while making important mathematical connections to their understanding (Furner, 2017a).

The bibliotherapy process is fairly easy to understand and implement. The therapeutic experience while reading a book happens to us each time we pick up a good book and say, 'This character is very much like me. I can relate to this person.' This interaction is known as identification, and the more we have in common with people we meet in our reading, the closer will be the identification process. That identification produces a sense of tension relief, or 'catharsis,' an emotional feeling that tells us we are not alone in facing our problems. As the learner enjoys the book and story and is able to identify with the character, they learn vicariously through the person in the storybook. We gain new ways of looking at troublesome issues we face and insight evolves. With this new insight, changed behavior may occur as real life situations similar to those experienced in the books are challenged and experienced (Furner, 2004). The three widely recognized stages of bibliotherapy are identifications, catharsis, and insight 
(Forgan, 2002; Halsted, 1994; Jack and Ronan, 2008); conversely, another less cited in the literature yet particularly enthralling for math teachers working with students anxious with math, is the concept of universalization (Slavson, 1950), or the acknowledgement that each person's problems are not unique. When teachers use universalization they realize and emphasize to their sensitive individuals that they are in this together and not alone. Thatcher and Fletcher (2008) discovered that most teachers do not realize or see the importance in using books and literature or bibliotherapy approach for neither addressing students' problems nor how to use such a practice in a school setting. The author hopes this paper helps to address some of these issues and advocates for more literature use during mathematics instruction (Furner, 2017b).

Children's books can help teachers guide the emotional development of their students' far more than intellectual discussion because stories directly affect human feelings (Forgan, 2002, 2003; Furner, 2004; Rozalski et al., 2010). Sometimes a skillful author can help young people connect with others who have similar problems. If books or short stories can touch young people emotionally, they may be much more receptive to ideas presented by the author than if they are presented to them in a lecture by a concerned teacher. Students who are unable to talk about their anxieties often can identify with characters in books strongly enough to experience the catharsis and acquire some significant discernments (Halsted, 1994; Heath et al., 2011).

In order for bibliotherapy to be successful, a meaningful follow-up discussion is required by the instructor (Forgan, 2002; Furner, 2004). Teachers also must recognize that to read a respectable book with a whole class is not automatically bibliotherapy, as there is a process one needs to follow as they put bibliotherapy into practice. It is very important that young people not only read books, but also become involved in discussions, counseling and follow-up procedures such as play-acting/role-play, innovative problem solving, and relaxation with artistic and musical activities and even some journal writing (Furner, 2004; Forgan, 2002, 2003; Hébert, 1991, 1995; Hébert and Furner, 1997). Bibliotherapy can be gratifying and also provide a time for firm self-analysis for the learner to better deal with possible obstacles that may be holding them back.

It is important that sensitive mathematics teachers' help students recognize that their abilities may vary from their peers and acknowledge that they may also have areas of weakness and assist them in developing self-esteem by becoming satisfied with who they are as individuals (Ableser, 2008). Teachers using bibliotherapy may be successful in doing so by making relations to the students' attitudes and feelings with the characters in storybooks (Regan and Page, 2008). Leininger et al. (2010), Burke (2009), and Kurtts and Gavigan (2008) have all established that there are a wide range of literature and picture books useful in shepherding bibliotherapy to address a wide range of conditions and societal concerns impacting young people today. The bottom line here is that using fairy tales or literature to teach mathematics can be beneficial for student in learning mathematics concepts in a more meaningful way, making important connections while allowing our young people to employ some creativity and imagination to the learning situation. In addition, the use of bibliotherapy is beneficial in that it can help some students in class who might struggle with either fears or unease about math or even the peer-pressure of being mathematically talented and considered a geek or nerd (Furner and Kenney, 2011).

\section{POSSIBLE MATH ACTIVITIES FOR TEACHERS TO TRY USING CHILDREN'S LITERATURE}

1. "Alphabet Snoop" is an activity used at Math Fairs in schools in Palm Beach County. In the activity using books and letters, the children predict which letter of the alphabet would occur most frequently in their reading books. The activity involves tallying with tally marks, individual graphing, class graphing, the use of calculators, and working together in groups or with families. It was very exciting and rewarding for the class as it incorporates children's literature and actual mathematics in a non-threatening way.

At the intermediate grade levels, students can also connect math and language concepts in a similar fashion. There are a series of books on the parts of speech by Ruth Heller that could be used to stimulate student interest as they relate to different parts of speech. These books could be used to identify different types of words and understanding their use, an important approach for English Language Learners (ELL) students. Some math skills that can be applied are:

- Assembling information and choosing an appropriate way to record and display.

- Averaging the usage of words and finding percentages of kinds of words used in different types of writing.

- Finding patterns in various forms of writing and expressing them in mathematical terms.

- Develop calculator skills when analyzing information.

These are a few of many ideas that you can develop as math teachers (Furner, 2018; Furner et al., 2005).

2. Another great idea to connect math and literature in the classroom is by using the book, The Grandfather Tang's Story, a Chinese folktale; this book uses tangrams to tell a whimsical story of meeting many creatures 


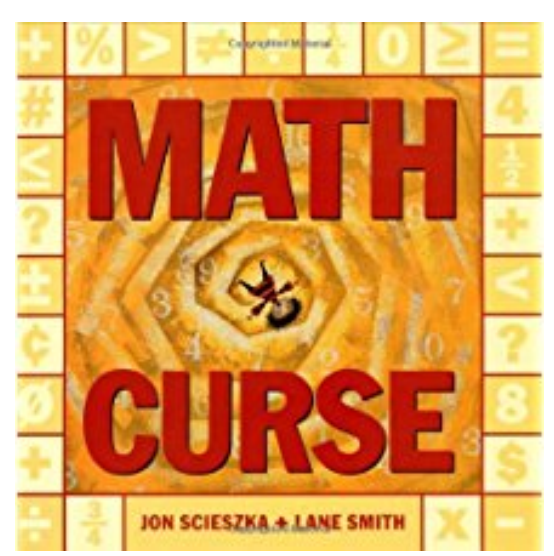

Figure 2. Math Curse

during the character's odyssey. This story can be read and used with transparencies and student activity pages geared to the appropriate grade levels to make this a participatory activity. The younger children can use pictures with outlined pieces in the drawing, while the older ones had only the basic outline and had to fill it in with the tangrams to make the animal mentioned on each page of the story. Children can also come up to the projector to work with the tangram pieces. It can be a very successful lesson at all grade levels. The use of literature to develop math concepts can go a long way in relieving children's math anxiety.

3. Teachers may like to use Shel Silverstien's poem, Smart, while teaching a unit on money. The poem starts out with a young boy receiving a one-dollar bill from his dad because he is "his smartest son" and he goes through a series of trades and transactions to receive other coins. He feels that each time he trades and receives more coins he has more than one. For example, swapping the one-dollar bill for two shiny quarters "cause two is more than one." After reading this poem to children, a teacher may use a journal writing prompt activity from the book, Write Starts: 101 Writing prompts for math, by McIntosh and Draper (1997), to have the students write about and then discuss what the error is in the story. Teachers may use many of the prompts in this book for follow-up of different children's literature. How is math used in your favorite sport? Maybe be a great writing prompt after students read the book, Sports Math Mania, by Hopping and Egan (1996). Teachers could use the prompt: One sign of a good problem solver is.... After reading the book Betcha!, by Murphy and Schindler (1997).

4. The practice of employing bibliotherapy within instruction has been a accepted means for reducing/overcoming math anxiety (Furner, 2017a). Teachers can read stories to their students, such as the book, Math Curse (See Figure 2) and/or A Gebra Named Al (Isdell, 2017), and then have student share how the characters relate to them and their own bad experiences with math for example. This can be a catharsis or therapeutic for children who may feel as the character did and help them see they are not the only ones that feel this way. Teachers may also encourage students to discuss and write about their own experiences with math and perhaps direct them to write their very own math autobiography or history with taking math courses over the years (Kitchens, 1995). Math teachers can just use literature to introduce, teach, or reinforce math concepts and then extend their students understanding allowing the students to discuss and write about their understanding through various activities (Furner, 2017b). It is critical in this day and age that we get through to all students and if literature can be a means to reach children and turn them on to mathematics then teachers need to integrate this best practice.

5. A Cloak for the Dreamer, by Friedman and Howard (1994) is a wonderful story to read to students to teach about two-dimensional geometry, spatial sense, and tessellations. Today there is almost an endless array of children's literature for teaching mathematics concepts to cover almost any NCTM and Sunshine State Standard Strand in mathematics from Number Sense, Measurement, Geometry, Algebraic Thinking, and Data Analysis, etc. A Cloak for the Dreamer (See Figure 3) tells a story of a tailor being hired by the Archduke to design and sew three new cloaks for himself and three dresses for his wife. The Archduke require the cloaks to be very colorful and also use shapes so that there are no gaps or overlaps so that he will not be cold and that no material will be wasted. The tailor has his three sons help him out with this task. This book explores tessellations. It can lead to a nice activity with manipulatives like pattern blocks where children can discover which shapes tessellate. Children's literature books like this are wonderful to read as a shared experience with children as they teach mathematical concepts within the context of a story making the learning of mathematics more meaningful to the learner.

Geist (2010) feels that an undesirable outlook related to mathematics and what has now been defined as "math anxiety" are somber impediments for young people PreK-College. In his paper, the literature is reviewed and critically evaluated in regards to the reasons of math phobias and its especially harmful 


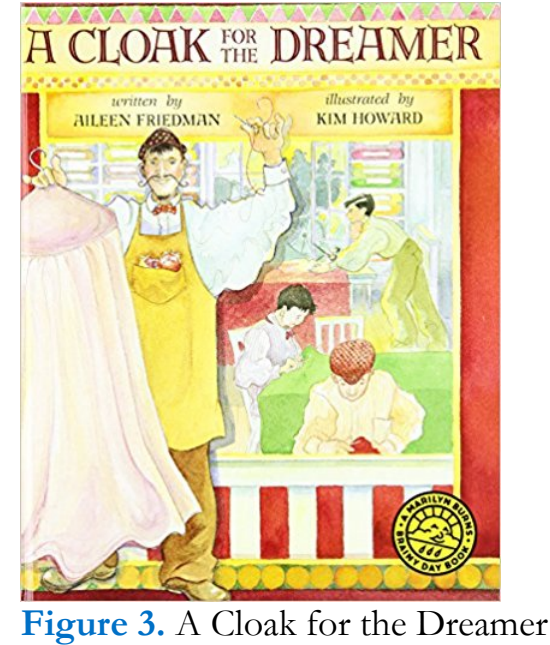

influence on learners who may be part of the "at-risk" population like, girls, special needs and particularly low socioeconomic status; Geist contends that an anti-anxiety curriculum is very important in improving students' confidence when working with the subject. Furner (2017b) hence feels that the use of best practices like incorporating children's literature in the teaching of mathematics to be sure to turn students on to the subject and assist in such an anti-anxiety curriculum.

\section{SUMMARY}

It was believed but unconfirmed that Albert Einstein said, "Everybody is a genius. But if you judge a fish by its ability to climb a tree, it will live its whole life believing that it is stupid" (Pettigrew, 2013). As educators we need to seek every which way to reach all types of students, turning them on to math and making them feel confident to do math and solve any problem, and also to have them use their creativity and imagination in the learning process. In today's times of increasing technology and with more of a push to better, prepare more young people for the STEM fields, children need be confident in their ability to do mathematics. With recent statistics showing students poor attitudes or declining scores in math as they increase in age for example from the Third International Mathematics and Science Study (TIMSS) (Schmidt, 1998) and other researchers like Burns (1998) and Jackson and Leffingwell (1999). Today, teachers can address the issue of math anxiety in their students by using children's literature and writing to help in reducing such anxiety by using books as a form of what is known as bibliotherapy. Teachers can also incorporate children's literature to help in preventing math anxiety from occurring by using such books in a shared setting with students making such connections to mathematics in more meaningful ways along with incorporating writing, discussion, and the use of manipulatives as they relate to the story in a children's literature book.

Teachers can do many things mentioned in this article in their own classrooms to help prevent and reduce math anxiety and better prepare young people for a STEM world. As a society, we must work together to extinguish the discomfort that our youth are having toward mathematics. It is important that our students feel confident in their ability to do mathematics in an age that relies so heavily on problem solving, technology, science, and mathematics. It really is a teachers' obligation to see that their students value and feel confident in their ability to do math, because ultimately a child's life: all decisions they will make and careers choices may be determined based on their disposition toward mathematics. As teachers, we must make the difference in our students' attitudes toward math! Using children's literature can help make better connections in math to the real world. Today it is important that we hear more students say, "Math is my favorite subject," "I am a good problem solver," "I am great at math!" or "I want to be and inventor or scientist!" Einstein said, "I am enough of an artist to draw freely upon my imagination. Imagination is more important than knowledge. Knowledge is limited. Imagination encircles the world" (Quote Investigator, n.d.). When teachers use fairy tales and children's literature in their classroom to teach math, they are allowing for creativity, imagination, and making connections for students better preparing them for a world that is ever advancing mathematically and technologically. We need to prepare our students for this new world of STEM where all young people are confident in their ability to do mathematics. The consensus of most of the research on this topic believe then that using children's literature is a great vehicle for teaching mathematics and better reaching young learners to then be able to better understand mathematics. 


\section{REFERENCES}

Abdullah, M. H. (2002). Bibliotherapy. ERIC Digest. Bloomington, IN: ERIC Clearinghouse on Reading, English, and Communication. (ERIC Document Reproduction Service No. ED470712). Available at: http://www.eric.ed.gov/PDFS/ED470712.pdf

Ableser, J. (2008). Authentic literacy experiences to teach and support young children during stressful times. Young Children, 63, 74-79.

Barnaby, D. (2015). The use of Children's Literature to Teach Mathematics to improve Confidence and Reduce Math Anxiety. A research paper submitted in conformity with the requirements for the degree of Master of Teaching, Department of Curriculum, Teaching and Learning, Ontario Institute for Studies in Education of the University of Toronto.

Betzalel, N. and Shechtman, Z. (2010). Bibliotherapy treatment for children with adjustment difficulties: A comparison of affective and cognitive bibliotherapy. Journal of Creativity in Mental Health, 5(4), 426-439. https://doi.org/10.1080/15401383.2010.527816

Boaler, J. (2008). What's math got to do with it? Helping children learn to love their least favorite subject-and why it's important for America. New York, NY: Penguin Group (USA) Inc.

Burke, A. (2009). Gifted and grieving: Why it is critical to offer differential support to gifted kids during times of loss. Gifted Child Today, 32(4), 30-37. https://doi.org/10.1177/107621750903200409

Burns, M. (1998). Math: Facing an American phobia. Sausalito, CA: Math Solutions Publications.

Clement, R. (1991). Counting on Frank. Milwaukee, WI: Gareth Stevens Publishing.

Doll, B. and Doll, C. (1997). Bibliotherapy with young people: Librarians and mental health professionals working together. Englewood, CO: Libraries Unlimited.

Forgan, J. W. (2002). Using bibliotherapy to teach problem solving. Intervention in School and Clinic, 38, 75-82. https://doi.org/10.1177/10534512020380020201

Forgan, J. W. (2003). Teaching problem solving through children's literature. Westport, CT: Teacher Ideas Press Libraries Unlimited.

Friedman, A. and Howard. K. (1994). A cloak for the dreamer. New York: Scholastic.

Furner, J. M. and Duffy, M. L. (2002). Equity for all students in the new millennium: Disabling math anxiety. Intervention in School and Clinic, 38(2), 67-74. https://doi.org/10.1177/10534512020380020101

Furner, J. M. (2004). Using bibliotherapy to overcome math anxiety. Academic Exchange Quarterly, 8, 209-213.

Furner, J. M., Yahya, N. and Duffy, M. L. (2005). 20 ways to teach mathematics: Strategies to reach all students. Intervention in School and Clinic, 41(1), 16-23. https:/ / doi.org/10.1177/10534512050410010501

Furner, J. M. and Kenney, C. (2011). Counting on Frank: Using bibliotherapy in mathematics teaching to prevent de-geniusing. Pythagoras, 32(2), Art. \#133, 7 pages. https://doi.org/10.4102/pythagoras.v32i2.133

Furner, J. M. (2016). Every student can be an Einstein: Addressing math anxiety in today's classrooms. Transformations, 2(2), 22-45.

Furner, J. M. (2017a). Helping all students become Einstein's using bibliotherapy when teaching mathematics to prepare students for a STEM world. Pedagogical Research, 2(1), 1-11. https://doi.org/10.20897/pedre.201701

Furner, J. M. (2017b). Using fairy tales and children's literature in the math classroom: Helping all students become Einstein's in a STEM world. Journal of Advances in Education Research, 2(2), 103-112. https://doi.org/10.22606/jaer.2017.22006

Furner, J. M. (2018). Planning a family math night-The how to's: A checklist for success. Transformations, 4(1), 1 of 16.

Geist, E. (2010). The anti-anxiety curriculum: Combating math anxiety in the classroom, Journal of Instructional Psychology, 37(1), 24-31.

Griffiths, R. and Clyne, M. (1991). Books you can count on: Linking mathematics and literature. Portsmouth, NH: Heinemann.

Halsted, J. W. (1994). Some of my best friends are books: Guiding gifted readers from pre-school to high schools. Dayton, OH: Ohio Psychology Press.

Heath, M. A., Moulton, E., Dyches, T. T., Prater, M. A. and Brown, A. (2011). Strengthening elementary school bully prevention with bibliotherapy. Communiqué Online, 39(8). Available at: http://www.nasponline.org/publications/cq/39/8/strengthening-bully-prevention.aspx

Heath, M.A., Sheen, D., Leavy, D., Young, E. and Money, K. (2005). Bibliotherapy: A resource to facilitate emotional healing and growth. School Psychology International, 26(5), 563-580. https://doi.org/10.1177/0143034305060792

Hébert, T. P. (1991). Meeting the affective needs of bright boys through bibliotherapy. Roeper Review, 13(4), 207-212. https://doi.org/10.1080/02783199109553360 
Hébert, T. P. (1995). Using biography to counsel gifted young men. The Journal of Secondary Gifted Education, 6, 208-219. https://doi.org/10.1177/1932202X9700800403

Hébert, T. P. and Kent, R. (2000). Nurturing social and emotional development in gifted teenagers through young adult literature. Roeper Review, 22, 167-171. https:/ / doi.org/10.1080/02783190009554027

Hébert, T. P. and Furner, J. M. (1997). Helping high ability students overcome math anxiety through bibliotherapy. The Journal of Secondary Gifted Education, 4, 164-178.

Hopping, L. J. and Egan, C. (1996). Sports math mania: Cool stats and number facts. New York: Sports illustrated for Kids, a division of Time, Inc.

Isdell, W. (2017). A Gebra Named Al. 2 ${ }^{\text {nd }}$ Edition. Morrisville, NC, USA: Lulu Publishing.

Jack, S. J. and Ronan, K. R. (2008). Bibliotherapy: Practice and research. School Psychology International, 29, 161-182. https://doi.org/10.1177/0143034308090058

Jackson, C. D. and Leffingwell, R. J. (1999). The Role of Instructor in Creating Math Anxiety in Students from Kindergarten through College. Mathematics Teacher, 92(7), 583-586.

Jeon, K., (1992). Bibliotherapy for gifted children. Gifted Child Today, 15, 16-19. https://doi.org/10.1177/107621759201500604

Kitchens, A. N. (1995). Defecting math anxiety. Chicago, IL: Richard D. Irwin, Inc.

Kurtts, S. A. and Gavigan, K. W. (2008). Understanding (dis)abilities through children's literature. Education Libraries, 31(1), 23-31.

Leininger, M., Dyches, T. T., Prater, M. A. and Heath, M. A. (2010). Newbery award winning books 1975-2009: How do they portray disabilities? Education and Training in Autism and Developmental Disabilities, 45(4), 583-596.

Lenkowsky, R. S. (1987). Bibliotherapy: A review and analysis of the literature. The Journal of Special Education, 21, 123-132. https://doi.org/10.1177/002246698702100211

McAndrew, E. M., Morris, W. L. and Fennell, F. S. (2017). Geometry-Related Children's Literature Improves the Geometry Achievement and Attitudes of Second-Grade Students. School Science and Mathematics, 117(1-2), 3451. https://doi.org/10.1111/ssm.12202

McIntosh, M. E. and Draper, R. J. (1997). Write Starts: 101 Writing prompts for math. White Plains, NY: Dale Seymour Publications.

McLeod, D. B. (1992). Research on affect in mathematics education: A reconceptualization. In D.A. Grouws (Ed.), Handbook of research on mathematics teaching and learning (pp. 575-596). New York, NY: Macmillan.

Muir, T., Livy, S., Bragg, L., Clark, J., Wells, J. and Attard, C. (2017). Engaging with Mathematics through Picture Books. Teaching Solutions, Australia, pp. 96. ISBN 978-1-925145-17-5

Murphy, S. J. and Schindler, S. D. (1997). Betcha! New York: Scholastic.

National Council of Teachers of Mathematics. (2000). Principles and standards for school mathematics. Reston, VA: NCTM.

National Council of Teachers of Mathematics. (1989). Curriculum and evaluation standards for school mathematics. Reston, VA: NCTM.

Neuschwander, C. and Geehan, W. (1999). Sir Cumference and the dragon of pi: A math adventure.

Pettigrew, T. (2013). Why we should forget Einstein's tree-climbing fish. Available at: https://www.macleans.ca/education/uniandcollege/why-we-should-forget-einsteins-tree-climbing-fish/

Quote Investigator, (n.d.). Available at: https:// quoteinvestigator.com/2013/01/01/einstein-imagination/

Regan, K. and Page, P. (2008). "Character" building: Using literature to connect with youth. Reclaiming Children and Youth, 16, 37-43.

Reis, S. M. and Renzulli, J. S. (2004). Current research on the social and emotional development of gifted and talented students: Good news and future possibilities. Psychology in the Schools, 41, $119-130$. https://doi.org/10.1002/pits.10144

Rozalski, M., Stewart, A. and Miller, J. (2010). Bibliotherapy: Helping children cope with life's challenges. Kappa Delta Pi Record, 47, 33-37.

Schmidt, W. H. (1998). Changing mathematics in the U.S.: policy implications from the third international mathematics and science study. Presentation at the $76^{\text {th }}$ Annual meeting of the National Council of Teachers of Mathematics, Washington, D.C., April 3, 1998.

Scieszka, J. and Smith, L. (1995). Math Curse. NY, NY: Viking Press.

Slavson, S. R. (1950). Analytic group psychotherapy with children, adolescents, and adults. New York, NY: Columbia University Press.

Sparks, S. D. (2011). Math anxiety explored in studies, Education Week, 30(31) p1.

Sridhar, D. and Vaughn, S. (2000). Bibliotherapy for all: Enhancing reading comprehension, self-concept, and behavior. Teaching Exceptional Children, 33, 74-82. https://doi.org/10.1177/004005990003300210 
Sullivan, A. K. and Strang, H. R. (2003). Bibliotherapy in the classroom: Using literature to promote the development of emotional intelligence. Childhood Education, 79, 74-80. https://doi.org/10.1080/00094056.2003.10522773

Thatcher, K. and Fletcher, K. (2008). Professionals' perceptions of the role of literacy in early intervention services. Psychology in the Schools, 45(7), 600-608. https://doi.org/10.1002/pits.20312

Weinstein, K. (2017). Children's literature as a tool to teach mathematics. Senior Honors Thesis-Eastern Michigan University, 516. Available at: http://commons.emich.edu/honors/516

\section{APPENDICES}

\section{Appendix A}

Dear Teacher Website: Children's Books with Mathematics Themes Website at: http://www.dearteacher.com/math-books

\section{Appendix B}

A List of Children's Literature Books to use to Teach Math by Math Strand

Primary Grade Level Children's Literature for Teaching Mathematics Concepts

\begin{tabular}{|c|c|c|}
\hline STRAND & TITLE OF BOOK & AUTHOR \\
\hline Number Sense, Concepts & Ten, Nine, Eight & Molly Bang \\
\hline \multirow{42}{*}{ and Operations } & How Many Bugs in a Box & David Carter \\
\hline & Six Brave Explorers & Kees Moerbeek and Carla Dijs \\
\hline & There were Ten in the Bed & By Child's Play \\
\hline & What Comes in 2's, 3's \& 4's. & Suzanne Aker \\
\hline & The Right Number of Elephants & Jeff Sheppard \\
\hline & Every Buddy Counts & Stuart J. Murphy \\
\hline & Anno's Counting Book & Mitsumasa Anno \\
\hline & Who Wants One? & Mary Serfozo \\
\hline & Twelve Ways to Get to Eleven & Eve Merriam \\
\hline & Rooster's Off to See the World & Eric Carle \\
\hline & Fish Eyes: A Book You Can Count On & Lois Ehlert \\
\hline & The Twelve Circus Rings & Seymour Chwast \\
\hline & Picking Peas for a Penny & Angela Shelf Medearis \\
\hline & One Hunter & Pat Hutchins \\
\hline & One Gorilla: A Counting Book & Atsuko Morozumi \\
\hline & The Line Up Book & Marisaoina Russo \\
\hline & Ten Black Dots & Donald Crews \\
\hline & Frog Counting Books & John Liebler \\
\hline & Animal Numbers & Bert Kitchen \\
\hline & One Fine Day & Nonny Hogragian \\
\hline & The Fox Went Out on a Chilly Day & Peter Spier \\
\hline & More, More, More, Said the Baby & Vera B. Williams \\
\hline & Fish Eyes & Lois Ehlert \\
\hline & Frog and Toad Together & Arnold Lobel \\
\hline & Tuesday & David Wiesner \\
\hline & The April Rabbits & David Cleveland \\
\hline & Two Ways to Count to Ten & Ruby Dee \\
\hline & Seven Little Rabbits & John Becker \\
\hline & The Icky Bug Counting Book & Jerry Palotta \\
\hline & How Many How Many How Many & Rick Walton \\
\hline & From One to One Hundred & Teri Sloat \\
\hline & Domino Addition & Lynette Long \\
\hline & The Crayon Counting Book & Pam M. Ryan and Jerry Pallotta \\
\hline & Ten Beads Tall & By Child's Play \\
\hline & One Crow: A Counting Rbyme & Jim Aylesworth \\
\hline & Counting on Calico & Phyllis L. Tildes \\
\hline & Ready, Set, Hop & Stuart J. Murphy \\
\hline & Leap Into Math & Jane Keegan \\
\hline & The Napping House & Audrey Wood \\
\hline & Two of Everything & Lilly Toy Hong \\
\hline & Eating Fractions & Bruce McMillan \\
\hline & Gator Pie & Louise Mathews \\
\hline
\end{tabular}


Furner / Children's Literature to Teach Math

\begin{tabular}{|c|c|c|}
\hline \multirow[t]{23}{*}{ Measurement } & Mouse's Birthday & Jane Yolen and Bruce Degen \\
\hline & The Best Bug Parade & Stuart Murphy \\
\hline & Inch by Inch & Leo Lionni \\
\hline & Is It Larger? Is It Smaller? & Tana Hoban \\
\hline & The Grouchy Ladybug & Eric Carle \\
\hline & Mice Twice & Joseph Law \\
\hline & "Smart" from Where the Sidewalk. Ends & Shel Silverstein \\
\hline & Alexander, Who Used to Be Rich Last Sunday & Judith Viorst \\
\hline & Rude Giants & Audrey Wood \\
\hline & Much Bigger than Martin & Steven Kellogg \\
\hline & The Very Hungry Caterpillar & Eric Carle \\
\hline & Who Sank the Boat & Pamela Allen \\
\hline & Temperature and You & Betsy and Guilio Maestro \\
\hline & \multicolumn{2}{|c|}{$\begin{array}{l}\text { Reading the Numbers: A Survival Guide to the Measurements, Mary Blocksma } \\
\text { Numbers and Sizes Encountered in Everyday Life }\end{array}$} \\
\hline & A Giraffe and a Half & Shel Silverstein \\
\hline & 26 Letters and 99 Cents & Tana Hoban \\
\hline & How Many Feet in the Bed? & Diane Johnston Hamm \\
\hline & How Big is a Foot? & Rolfe Myller \\
\hline & Picking Peas for a Penny & Angela Shelf Medearis \\
\hline & The Tortoise and the Hare & Janet Stevens \\
\hline & Measuring & David Kirkby \\
\hline & Mr. Archimedes' Bath & Pamela Allen \\
\hline & King Bidgood's in the Bathtub & Audrey Wood \\
\hline \multirow{13}{*}{$\begin{array}{l}\text { Geometry and Spatial } \\
\text { Sense }\end{array}$} & Seeing Shapes & By Playschool \\
\hline & Changes, Changes & Pat Hutchings \\
\hline & The Shape of Me and Other Stuff & Dr. Seuss \\
\hline & Color Zoo & Lois Ehlert \\
\hline & The Adventures of Terry Tangram & By Learning Resources \\
\hline & Shapes & David Kirky \\
\hline & The Shapes Game & Paul Rogers \\
\hline & The Very Hungry Caterpillar & Eric Carle \\
\hline & The Greedy Triangle & Marilyn Burns \\
\hline & My Very First Book of Shapes & Eric Carle \\
\hline & Shapes, Shapes, Shapes & Tana Hobin \\
\hline & Circles, Triangles, and Squares & Tana Hobin \\
\hline & What is Symmetry & Mindel and Harry Sitomer \\
\hline STRAND & TITLE & AUTHOR \\
\hline \multirow{14}{*}{ Algebraic Thinking } & The Button Box & Margarette S. Reid \\
\hline & The Very Hungry Caterpillar & Eric Carle \\
\hline & Somethings Go Together & Charlotte Zolotow \\
\hline & The Grey Lady and the Strawberry Snatcher & Molly Bang \\
\hline & Patterns & David Kirkby \\
\hline & The Three Billy Goats Gruff & Marcia Brown \\
\hline & Caps for Sale & Esphyr Slobodkina \\
\hline & The Doorbell Rang & Pat Hutchins \\
\hline & Number Ideas Through Pictures & Mannis Charosh \\
\hline & Sam Johnson and the Blue Ribbon Quilt & Lisa Campbell Ernst \\
\hline & Too Much Noise & Ann McGovern \\
\hline & Eight Hands Round & Ann Whitford Paul \\
\hline & AMy Name is Alice & Jane Bayer \\
\hline & Why Mosquitoes Buгz in People's Ears & Verna Aardema \\
\hline STRAND & TITLE & AUTHOR \\
\hline \multirow{9}{*}{ Analysis and Probability } & The Button Box & Margarette S. Reid \\
\hline & Moira's Birthday & Robert Munsch \\
\hline & Sorting & David Kirkby \\
\hline & Anno's Magic Seeds & Mitsumasa Anno \\
\hline & Don't Forget the Bacon & Pat Hutchins \\
\hline & Eating the Alphabet: Fruits and Vegetables from $A$ to $Z$ & Lois Ehlert \\
\hline & The Best Vacation Ever & Stuart J. Murphy \\
\hline & Probability & Charles F. Linn \\
\hline & Happy Birthday, Sam & Pat Hutchins \\
\hline
\end{tabular}


European Journal of STEM Education, 2018, 3(3), 14

Intermediate Grade Level Children's Literature for Teaching Mathematics Concepts

\section{STRAND}

Number Sense, Concepts and Operations

\section{TITLE}

Seven Blind Mice

Goldilocks and the Three Bears

A Chair for my Mother

Sylvester and the Magic Pebble

Each Orange has Eight Slices: A Counting Book

Clocks and More Clocks

Henry's Important Date

How Much is a Million

The King's Chessboard

Fraction Fun

Each Orange has 8 Slices

One Grain of Rice

The 500 Hats of Bartholomew Cubbins

Palindromes and Anagrams

Henry Huggins

A Million Fish...More or Less

Too Hot to Hoot

Think About Shape

Sea Squares

Bunches and Bunches of Bunnies

Math Curse

Anno's Mysterious Multiplying Jar

Charlie and the Chocolate Factory

Sideways Stories from Wayside School

Counting on Frank

Piqza for Breakfast

Moja Means One Swabili Counting Book.

If You Made a Million

Today I Was Ten (From Don't Ever Cross a Crocodile)

Our Solar System

The Magic Schoolbus Lost in the Solar System

On an Average Day

Our Solar System

The Phantom Tollbooth
Always Room for One More

\section{AUTHOR}

Ed Young

James Marshall

Sorche Nie Leodhas

Vera B. Williams

William Steig

Paul Giganti

Pat Hutchins

Robert Quackenbush

David M. Schwartz

David Birch

David A. Adler

Paul Giganti

Demi

Dr. Seuss

Howard Bergerson

Beverly Cleary

Patricia McKissack

Marvin Terban

Henry Pluckrose

Joy Hulme

Louise Mathews

Jon Scieszka and Lane Smith

Masaichiro and Misumasa Anno

Roald Dahl

Louis Sachar

Rod Clement

Mayann Kovalski

Muriel Feelings

David Schwartz

Kaye Starbird

Isaac Asimov

Joanna Cole

Thomas Heymann

Seymour Simon

Norton Juster

\begin{tabular}{|c|c|c|}
\hline STRAND & TITLE & AUTHOR \\
\hline \multirow[t]{16}{*}{ Measurement } & Frog and Toad are Friends & Arnold Lobel \\
\hline & Time Flies & Eric Rothman \\
\hline & The Whipping Boy & Sid Fleischman \\
\hline & The Boy of the Three-Year Nap & Dianne Snyder \\
\hline & Paul Bunyan & Steven Kellogg \\
\hline & Patterns & David Kirkby \\
\hline & The Relative Came & Cynthia Rylant \\
\hline & The Crow and the Pitcher & Mary Hill Arbuthot \\
\hline & There Were Monkeys in My Kitchen & Sheree Fitch \\
\hline & Math Curse & Jon Scieszka and Lane Smith \\
\hline & George's Marvelous Medicine & Roald Dahl \\
\hline & Tuesday & David Wiesner \\
\hline & Sideways Stories from Wayside School & Louis Sachar \\
\hline & If You Made a Million & David M. Schwartz \\
\hline & Pigs will be Pigs & Amy Axelrod \\
\hline & Measures and Space & David Kirkby \\
\hline STRAND & TITLE & AUTHOR \\
\hline Geometry and Spatial & How a House Happens & Jan Adkins \\
\hline \multirow[t]{8}{*}{ Sense } & Arrow to the Sun & Gerald McDermott \\
\hline & Flat Stanley & Jeff Brown \\
\hline & Anno's Math Games & Mitsumasa Anno \\
\hline & Anno's Math Games II & Mitsumasa Anno \\
\hline & Anno's Math Games III & Mitsumasa Anno \\
\hline & Sideways Stories from Wayside School & Louis Sachar \\
\hline & Grandfather Tang's Story & Ann Tompert \\
\hline & M is for Mirror Book & Duncan Birmingham \\
\hline
\end{tabular}




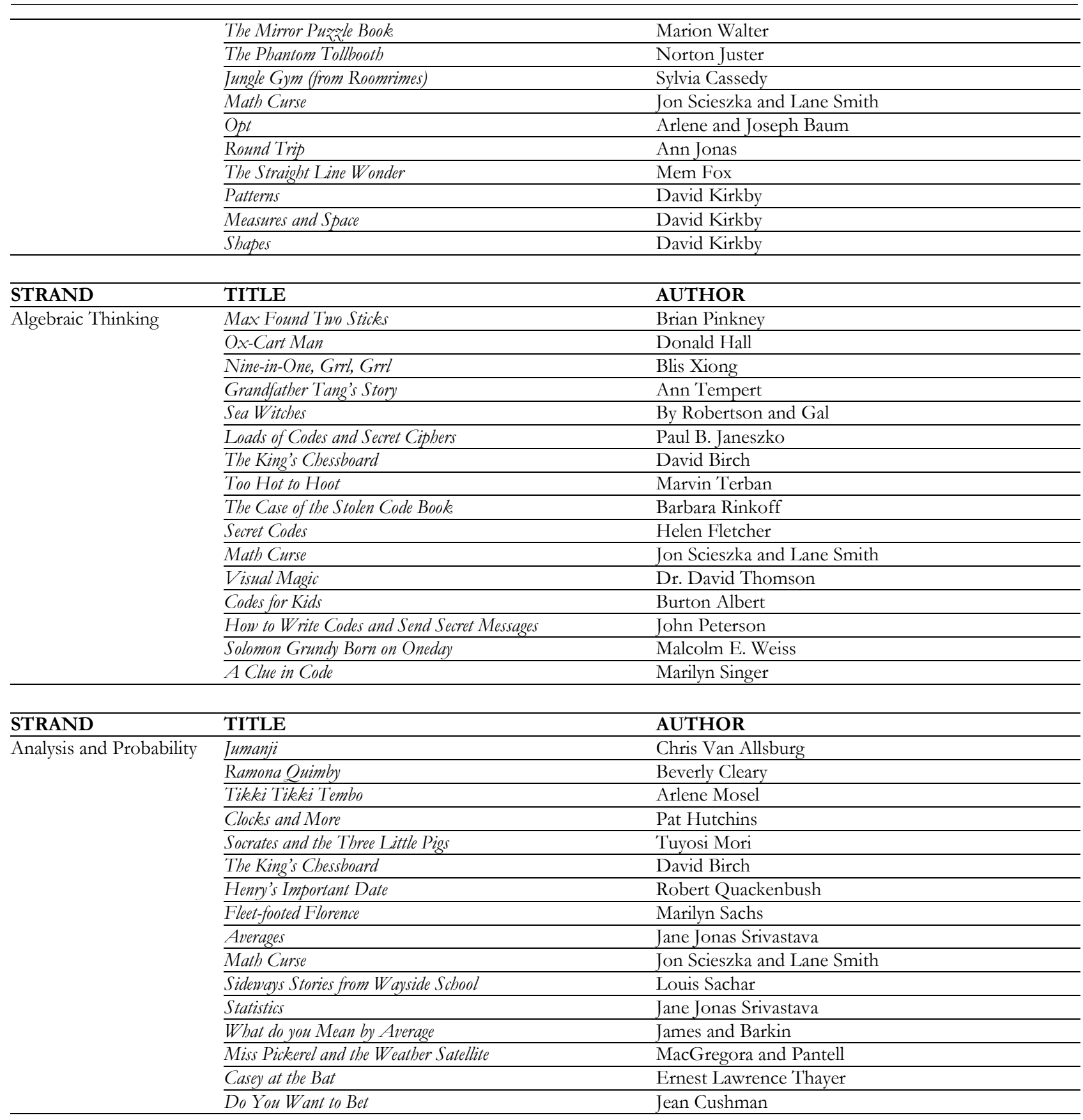

\section{AUTHOR BIO}

Joseph M. Furner, Ph.D. is a Professor of Mathematics Education in the Department of Teaching and Learning at Florida Atlantic University in Jupiter, Florida. He received his Bachelor's degree in Education from the State University of New York at Oneonta and his Masters and Ph.D. in Curriculum and Instruction and Mathematics Education from the University of Alabama. His scholarly research relates to math anxiety, the implementation of the national and state standards, English language issues as they relate to math instruction, the use of technology in mathematics instruction, math manipulatives, family math, and children's literature in the teaching of mathematics. Dr. Furner is the founding editor of Mathitudes Online at: http://www.coe.fau.edu/centersandprograms/mathitudes/. He is the author of more than $80+$ papers. Dr. Furner has worked as an educator in New York, Florida, Mexico, and Colombia. He is concerned with peace on earth and humans doing more to unite, live in Spirit, and to care for our Mother Earth and each other. He is the author of Living Well: Caring Enough to Do What's Right. Dr. Furner currently lives with his family in Palm Beach, Florida. He enjoys his job, family, civic and church involvement and the beach. Please feel free to write to him at: jfurner@fau.edu. 